\title{
PIONEER PARK AND IT'S PIONEER
}

\author{
By WM. M. MCLAughLiN ${ }^{1}$
}

In the brief moments allotted to me here at Pioneer park I do not know what would be more fitting and appropriate for my subject than to devote my time to saying something of this hill and of the great pioneer Barlow Granger, who built his home here in 1858, and who resided here continuously for almost a half century.

This hill is the product of the Kansan ice drift of some seven hundred thousand years ago.

I have been at this park just once before, at that time enjoying a Sunday picnic, several years ago. I recall visiting at that time with an old coal miner who was resting on one of the benches in the park, and he told me of finding an oak log in the vicinity of this hill, under the first strata of coal. The logs found below the first strata of coal were laid there by the Kansan glacier. This hill, through its entire depth, has mingled with its rock and earth gold, silver, copper, and iron, a contribution of the Kansan drift. Even a handful of dirt at its surface contains all of these metals. There is more timber in Iowa buried beneath its surface than is growing on its surface today. These logs sleep under the cities and towns and beneath the Iowa corn and clover fields. Some were buried by the Wisconsin drift forty thousand years ago. Many of such logs are still in a splendid state of preservation.

For seven hundred thousand years this hill has frowned above the prairies and overlooked the waters of the winding Raccoon and Des Moines rivers, and gazed down upon their enchanted valleys.

Barlow Granger was born in New York state on the 31st day of May, 1816. The career of every child is wrapped in the secret of the future. Fate forever loves to mystify and conceal our future and our plans. Someone

\footnotetext{
${ }^{1}$ An address given at a Masonic gathering September 18, 1943, at Pioneer Park, Des Moines. Mr. McLaughlin died at his home in Des Moines, September 15, 1945.
} 
has said that every president of this republic became president by accident, by some apt words of wisdom, or by some happy incident called fate. Who would dream, or what fortuneteller, gazing through his crystal, could vision the future of our famous pioneer? There were in this broad land myriads of hills like this and valleys multitudinous; likewise with winding rivers. Yet, fate decreed that the New York state babe would become a pioneer on this particular hill; that this hill would become his beloved home and abiding place for half a century; and upon this hill he would grow venerable with age and that his years would be numbered in the eighties; that he would be a beloved citizen of Des Moines and known throughout the state with honor and distinction, and that on this very hill his eyes would close forever in the mystery called Death.

Man's life is like that; much like a piece of driftwood floating on some meandering stream; it is in the hands of the Infinite; a thousand different things may determine its destiny; perhaps the mere sigh of a zephyr, an eddy, or turn of the current may fix and establish its final lodging place.

The ambition and spirit of youth is the moving force of life. Man goeth, but knoweth not where he be going. Barlow Granger never heard of this hill now "Pioneer Park" until that far away August morning in the year 1848. Whether his location on this hill be charged to fate or destiny, accident or to some happy chance, makes little difference. The fact that he lived here and that it was his abiding place, his pioneer refuge and home for fifty years, is of particular importance. Barlow Granger was in spirit and courage, in ambition and adventure, the typical American pioneer. He was of the type that built the state of Iowa, that aided so materially in placing our institutions on the granite foundation of justice and equality.

It was fitting, aye, simply splendid, that the home of Barlow Granger should become a city park and that "Pioneer Park" should be its name. 


\section{The Printer Journeyed West}

Barlow Granger in his youth became a journeyman printer and was thus employed in many of the outstanding cities of the east, also at Cleveland, Cincinnati, and Detroit, and finally at St. Paul and St. Louis.

In the year 1847 he rode a steamboat on the Mississippi river from St. Paul to St. Louis, where for a brief time he resided and worked at his trade. In August of 1848, with a New York friend, a man named Jones, whom he had accidentally met in St. Louis, he came up the Mississippi river by boat to Keokuk. From Keokuk by stage they made their way north to Mount Pleasant. There Barlow Granger and his friend procured a horse and buggy and, following the emigrant wagon trail, traveled over the prairies to Des Moines. Here they lingered a couple of days, driving about and looking over Des Moines, which consisted of a deserted fort and some scattered shanties. But Des Moines did not look good to them and they concluded to move on, and in leaving they crossed the Raccoon river and came by this very hill. They stopped upon its summit and looked out over the prairies and up and down these winding rivers. They stood in awe, entranced by the beauty of the scene that opened up before them. They then and there resolved that Des Moines was good enough for them. Barlow Granger soon purchased eighty acres which included this hill. The man named Jones purchased Terrace Hill, which afterwards became the home of B. F. Allen, and eventually the home of the late F. M. Hubbell. ${ }^{2}$

From his home overlooking this enchanted valley, the adjacent prairies, and these winding rivers he could view the officers' quarters and barracks of old Fort Des Moines. From his own doorstep he saw the city grow and prosper; he saw the construction of the old three-story brick capitol; he saw the present state capitol going up stone upon stone and saw it crowned with its golden

\footnotetext{
${ }^{2} \mathrm{Mr}$. Granger's traveling companion was James B. Jones, as he subsequently related at a meeting of the Early Settlers association. Granger said he was never disappointed in his selection, having realized all his expectations, while Jones became dissatisfied with his, and subsequertly disposed of the tract.
} 
dome. Through the years he saw the early beams of the God of Day play upon its summit and each evening he saw the dome reflect in burnished gold the last lingering rays of the setting sun. Through the summer days he heard the whistle of the steamboat on the river and saw the smoke from its stack wafted over these virgin valleys. Steamboats were an every day affair. "Tac" Hussey tells in his History of Des Moines that in the summer of 1862 he saw twenty-five steamboats at the wharf in Des Moines. Who could desire to live a more romantic and rustic life than that lived by Barlow Granger on this ancient hill? Here his nightly serenade was the howl of the timber wolf and his morning vespers were the drumming glory of the prairie chicken.

\section{Des MoINes' FiRst Editor}

Barlow Granger for a brief time edited the first newspaper in Des Moines, called the Star. His editorial offices were in one of the old barracks of Fort Des Moines. Later he became a lawyer and then prosecuting attorney of Polk county. For one year he filled the position of circuit judge of the Polk county circuit court. A shingle in front of his law office had upon it the following words:

\section{BARLOW}

Attorney and Counsellor at Law

\section{GRANGER}

"Barlow attends to all business in his line, And Granger to some that ain't."

During Barlow Granger's career as a lawyer in Des Moines, Polk county had an able bar, and Barlow Granger is said to have ranked high as a lawyer and the equal of the best lawyers of Des Moines.

He was honored by being on the staff of Governor Stephen Hempstead and there received the title of colonel.

On the 31st day of May, 1904, some fifty business men journeyed to this hill and to the home of Barlow Granger in honor of his 88th birthday. Louis Harbach, one of the number, placed on one of his fingers a heavy gold ring 
with a "brilliant setting". Less than a year later the morning Register in a headline advised the people of Des Moines and Iowa that the venerable and beloved pioneer was dead. His widow continued to reside in the old home for several years. This hill was "Home, Sweet Home" to her.

What could have been more logical and appropriate than that the city of Des Moines should honor this famed pioneer and at the same time honor itself by acquiring: this beautiful hill, including forty-six and three-fourths acres, of the old Granger homestead, for a city park, and giving it the name "PIONEER PARK"? All honor to the city and its councilmen of the years 1917 and 1919, who had the wisdom and foresight to accomplish this most gracious undertaking.

\section{QUARICENTENNIAL OF PRINTING IN NORTH AMERICA}

Many years which have ended in nine have been important in the annals of printing. It was in 1539,410 years ago, that Juan Pablos is known to have established what is believed to have been the first press in the New World, in Mexico City. One hundred years later, in 1639, Stepen Daye in Cambridge, Massachusetts, began operating the first press in English-speaking North America.

The year 1949 also is the 400th anniversary of the printing of the Book of Common Prayer in England. And among the states, North Carolina is not the only one celebrating an important anniversary (200th) of the establishment of a first press. In Connecticut it is the 240 th anniversary; the 160th in what is now the District of Columbia; the 130th in Arkansas; the 110th in Idaho; the 100th in Minnesota and Utah and the 90th in Arizona and Colorado. All told, there are a dozen such anniversaries being noted in 1949. - William S. Powell, in the North Carolina Historical Review. 
Copyright of Annals of Iowa is the property of State of Iowa, by \& through the State Historical Society of Iowa and its content may not be copied or emailed to multiple sites or posted to a listserv without the copyright holder's express written permission. However, users may print, download, or email articles for individual use. 